\title{
Use of MKSAP 16 for American Board of Internal Medicine Examination
}

Melissa Genarelli ${ }^{1}$, Wilbert S. Aronow ${ }^{2}$

\author{
${ }^{1}$ Divisions of General Internal Medicine, Westchester Medical Center/New York \\ Medical College, Valhalla, NY, USA \\ 2Divisions of Cardiology, Westchester Medical Center/New York Medical College, \\ Valhalla, NY, USA
}

Submitted: 22 February 2013

Accepted: 25 February 2013

Arch Med Sci 2015; 11, 6: 1354-1355

DOI: 10.5114 /aoms.2015.56365

Copyright $\odot 2015$ Termedia \& Banach

\author{
Corresponding author: \\ Wilbert S. Aronow MD, FACC, \\ FAHA \\ Cardiology Division \\ New York Medical College \\ Macy Pavilion \\ Room 138, Valhalla \\ NY 10595, USA \\ Phone: 011914-493-5311 \\ Fax: 011914-235-6274 \\ E-mail:wsaronow@aol.com
}

In reviewing MKSAP 16 in preparation for an American Board of Internal Medicine recertification examination, Dr. Melissa Gennarelli, an internist at Westchester Medical Center/New York Medical College, asked Dr. Wilbert S. Aronow, a Professor of Cardiology at Westchester Medical Center/New York Medical College, 2 questions. The first question was why he currently recommends that diabetics with hypertension should have their systolic blood pressure reduced to $<140 \mathrm{~mm} \mathrm{Hg}$ when MKSAP 16 (page 29 of Cardiovascular Medicine) recommends a systolic blood pressure goal of $<130 \mathrm{~mm} \mathrm{Hg}$. The second question was why he does not use dronedarone to treat high-risk patients with permanent atrial fibrillation when MKSAP 16 (page 52 of Cardiovascular Medicine) recommends the use of dronedarone in patients with atrial fibrillation to reduce hospitalization for cardiovascular events or mortality.

In reply to the first question, Dr. Aronow stated that on the basis of clinical trial data, the 2009 European Society of Hypertension guidelines [1], the American College of Cardiology Foundation/American Heart Association 2011 expert consensus document on hypertension in the elderly [2], and an excellent review article on this topic [3] recommend a systolic blood pressure goal of $<140 \mathrm{~mm} \mathrm{Hg}$ in diabetics with hypertension. The 2013 American Diabetes Association guidelines recommend a systolic blood pressure goal of $<140 \mathrm{~mm} \mathrm{Hg}$ in most diabetics with hypertension [4].

In reply to the second question, Dr. Aronow stated that the Permanent Atrial Fibrillation Outcome Study Using Dronedarone on Top of Standard Therapy (PALLAS) randomized 3,236 patients with permanent atrial fibrillation and risk factors for major vascular events to treatment with dronedarone or double-blind placebo [5]. This study was stopped for safety reasons with a median follow-up of 3.5 months because dronedarone increased the rates of heart failure, stroke, and cardiovascular mortality in patients with permanent atrial fibrillation at risk for major vascular events [5].

\section{Conflict of interest}

The authors declare no conflict of interest. 


\section{References}

1. Mancia G, Laurent S, Agabiti-Rosei E, et al. Reappraisal of European guidelines on hypertension management: a European Society of Hypertension Task Force document. Blood Press 2009; 18: 308-47.

2. Aronow WS, Fleg JL, Pepine CJ, et al. ACCF/AHA 2011 expert consensus document on hypertension in the elderly: a report of the American College of Cardiology Foundation Task Force on Clinical Expert Consensus Documents. Developed in collaboration with the American Academy of Neurology, American Geriatrics Society, American Society for Preventive Cardiology, American Society of Hypertension, American Society of Nephrology, Association of Black Cardiologists, and European Society of Hypertension. J Am Coll Cardiol 2011; 57: 2037-114.

3. Ferrannini E, Cushman WC. Diabetes and hypertension: the bad companions. Lancet 2012; 380: 601-10.

4. American Diabetes Association. Standards of medical care in diabetes: 2013. Diabetes Care 2013; 36 (Suppl. 1): S11-66.

5. Connolly SJ, Camm AJ, Halperin JL, et al. Dronedarone in high-risk permanent atrial fibrillation. $\mathrm{N}$ Engl J Med 2011; 365: 2268-76. 